\title{
Profibrotic mediators in tendon disease: a systematic review
}

\author{
Wataru Morita ${ }^{1,2^{*}}$ (D), Sarah Jane Bothwell Snelling ${ }^{1,2}$, Stephanie Georgina Dakin ${ }^{1,2}$ and Andrew Jonathan Carr ${ }^{1,2}$
}

\begin{abstract}
Background: Tendon disease is characterized by the development of fibrosis. Transforming growth factor beta (TGF- $\beta$ ), bone morphogenic proteins (BMPs) and connective tissue growth factor (CTGF) are key mediators in the pathogenesis of fibrotic disorders. The aim of this systematic review was to investigate the evidence for the expression of TGF- $\beta$, BMPs and CTGF along tendon disease progression and the response of tendon cells to these growth factors accordingly.

Method: We conducted a systematic screen of the scientific literature using the Medline database. The search terms used were "tendon AND TGF- $\beta$," "tendon AND BMP" or "tendon AND CTGF." Studies of human samples, animal tendon injury and overuse models were included.

Results: Thirty-three studies were included. In eight studies the expression of TGF- $\beta$, BMPs or CTGF was dysregulated in chronic tendinopathy and tendon tear patient tissues in comparison with healthy control tissues. The expression of TGF- $\beta$, BMPs and CTGF was increased and showed temporal changes in expression in tendon tissues from animal injury or overuse models compared with the healthy control (23 studies), but the pattern of upregulation was inconsistent between growth factors and also the type of animal model. No study investigated the differences in the effect of TGF- $\beta$, BMPs or CTGF treatment between patient-derived cells from healthy and diseased tendon tissues. Tendon cells derived from animal models of tendon injury showed increased expression of extracellular matrix protein genes and increased cell signaling response to TGF- $\beta$ and BMP treatments compared with the control cells (two studies).

Conclusion: The expression of TGF- $\beta$, BMPs and CTGF in tendon tissues is altered temporally during healing in animal models of tendon injury or overuse, but the transition during the development of human tendon disease is currently unknown. Findings from this systematic review suggest a potential and compelling role for TGF- $\beta$, BMPs and CTGF in tendon disease; however, there is a paucity of studies analyzing their expression and stimulated cellular response in well-phenotyped human samples. Future work should investigate the dynamic expression of these fibrotic growth factors and their interaction with tendon cells using patient samples at different stages of human tendon disease.
\end{abstract}

Keywords: Tendon, Tendinopathy, Tendon tear, Fibrosis, Transforming growth factor beta, Bone morphogenic protein, Connective tissue growth factor

\footnotetext{
* Correspondence: wataru.morita@ndorms.ox.ac.uk

'Botnar Research Centre, Nuffield Department of Orthopaedics,

Rheumatology and Musculoskeletal Sciences, University of Oxford, Nuffield

Orthopaedic Centre, Windmill Road, Headington, Oxford OX3 7LD, UK

${ }^{2} \mathrm{NIHR}$ Oxford Biomedical Research Unit, Botnar Research Centre, University of

Oxford, Windmill Road, Headington, Oxford OX3 7LD, UK
}

(c) The Author(s). 2016 Open Access This article is distributed under the terms of the Creative Commons Attribution 4.0 International License (http://creativecommons.org/licenses/by/4.0/), which permits unrestricted use, distribution, and reproduction in any medium, provided you give appropriate credit to the original author(s) and the source, provide a link to the Creative Commons license, and indicate if changes were made. The Creative Commons Public Domain Dedication waiver (http://creativecommons.org/publicdomain/zero/1.0/) applies to the data made available in this article, unless otherwise stated. 


\section{Background}

Tendon diseases are increasingly common fibrotic disorders $[1,2]$ and account for a third of all musculoskeletal complaints [3]. The patella, Achilles and rotator cuff (RC) tendons are the most frequently affected sites [4]. Tendon disorders are generally described by the term "tendinopathy" that includes diseases of the tendon and also tendon-bone junctions, namely enthesopathy or enthesitis [5]. The development of tendon disease has been proposed to start from an acute reactive tendinopathy, and subsequent dysregulated healing or disrepair may cause progression to chronic tendinopathy $[6,7]$. The etiology is multifactorial, with overuse, trauma, aging and genetic predisposition regarded as notable risk factors $[8,9]$. Recent studies have indicated the key role of inflammation in the homeostasis and healing of tendon, and its dysregulation may therefore contribute to the accumulation of mechanically inferior fibrotic tendon tissue $[10,11]$. This results in an inappropriate function of the tendon, higher risk of reinjury [12] and tendon rupture [6]. Torn tendons are usually treated by surgical repair, but the postoperative retear rate remains high at around $40 \%$ in operated RC tears [13]. A clinical need therefore exists for improved understanding of the mechanisms underlying both tendon disease and successful repair.

Studies of fibrotic diseases in other organs such as the liver, lung and kidney have implicated the members of the transforming growth factor beta (TGF- $\beta$ ) superfamily as key fibrotic growth factors [14] and proposed them as effective biomarkers for fibrotic changes [15]. TGF- $\beta$ and bone morphogenic proteins (BMPs) are the two major members of the superfamily, the former known as a key regulator of fibrosis and repair. BMPs also contribute to fibrosis by guiding cell differentiation and the subsequent synthesis of extracellular matrix (ECM) proteins. TGF- $\beta$ and BMPs both utilize the canonical Smad cell-signaling pathway, which also has been suggested to have crosstalk between the two [16]. Connective tissue growth factor (CTGF) belongs to the CCN family (CTGF, cysteine rich protein (Cyr61) and nephroblastoma overexpressed gene (Nov)) but is one of the key profibrotic mediators and acts closely with TGF- $\beta$ as its downstream mediator. The expression of these growth factors has been reported to change over the progression of fibrotic liver diseases from hepatitis, cirrhosis to carcinogenesis $[17,18]$, and the cellular response to these fibrotic mediators differs accordingly [19].

The aim of this study was to investigate the role of TGF- $\beta$, BMPs and CTGF in the pathophysiology of tendon disease via a systematic review. The first objective was to investigate the gene and protein expression of TGF- $\beta$, BMPs and CTGF in diseased tendons along the development of disease from tendinopathy to tear in comparison with the healthy tendon tissues. The second objective was to investigate whether cellular response to treatment with TGF- $\beta$, BMPs or CTGF was dysregulated in tendon cells from diseased tendons. Animal studies of tendon injury and overuse models were also reviewed. We hypothesized that the expression of TGF- $\beta$, BMPs and CTGF in diseased or injured tendon tissues and the cellular responses to these growth factors would change between normal tendon, early and late disease or healing. Understanding disease progression in relation to the expression and cellular activity of these key fibrotic mediators should help identify their potential role in the pathogenesis of tendon disease.

\section{Methods}

\section{Search strategies}

This systematic review was designed, undertaken and reported based on the Preferred Reporting Items for Systematic Reviews and Meta-Analyses (PRISMA) Statement and the Cochrane guidelines. The inclusion criteria and analysis methods were defined and stated in a protocol prior to the study. Scientific literature was obtained using the Medline electronic database. The search was conducted in September 2016 with the following search terms: "tendon AND TGF- $\beta$," "tendon AND BMP" and "tendon AND CTGF." The reports retrieved by the searches were compiled and duplicates were removed. The abstract of the papers was screened before the assessment for eligibility by reviewing the full text of the articles.

The studies reporting the expression of the growth factors in diseased human tendon tissues, animal models of tendon injury or overuse had to relate to the midsubstance of tendon or tendon-to-bone enthesis, and therefore studies on muscle-tendon junctions, ligament reconstruction using tendon grafts and other soft tissues (e.g. muscles, ligaments, bursa and synovial tissues) were excluded. The included studies had to involve a control group. The animal studies of injury healing had to follow and report the temporal course of repair in comparison with the control. Animal overuse models were included when the development of tendinopathy was verified based on histological findings such as infiltration of inflammatory cells, changes in cellularity/cell phenotype, vascularity and disorganized or ruptured collagen fibers $[5,20]$. The in vitro studies had to relate cell phenotype depending on the presence of disease to the cellular activity in response to treatment by TGF- $\beta$, BMPs or CTGF. Review articles, case reports and studies that were not reported in English were excluded. There was no limitation in the year of data entry, although all of the results were published after 1985 .

The data extracted were summarized using a spreadsheet that included patient or animal model characteristics, 
method of tissue or cell analysis, the control group, results and statistical methods.

\section{Study selection}

The search yielded 592 results (Fig. 1). There were 532 papers after duplicates were removed, and 442 papers remained after review articles, case reports and articles that were not in English were removed. Screening of the paper abstracts based on the criteria set beforehand reduced this number to 43. Assessment for eligibility through the full text resulted in 33 papers meeting the criteria. The reasons for excluding the remaining $10 \mathrm{pa}-$ pers were no control group $(n=3)$, no temporal comparison of the expression of the growth factors in animal studies $(n=4)$ and no verification of the development of tendinopathy in an animal overuse model $(n=3)$. The papers that met the inclusion criteria are summarized in Tables 1, 2 and 3.

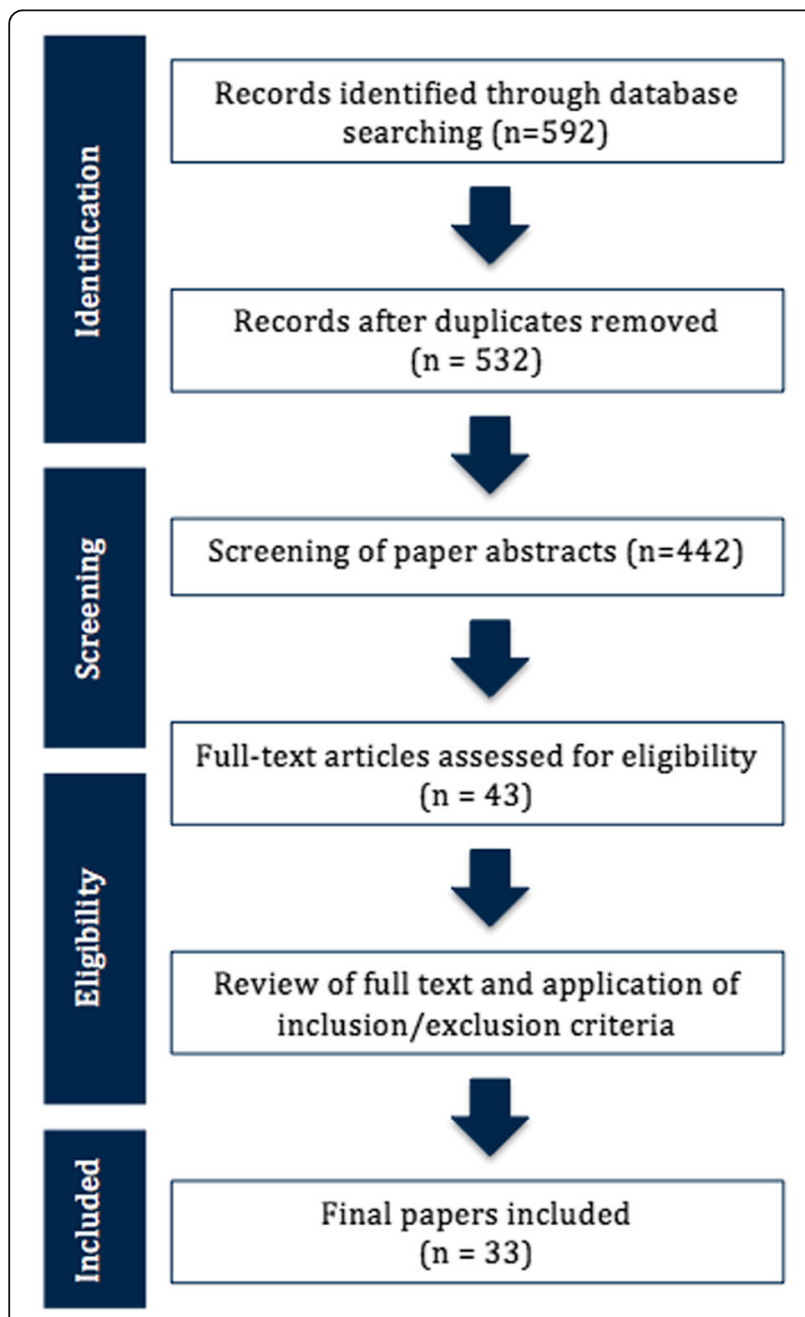

Fig. 1 Flow chart of the systematic review protocol

\section{Study characteristics}

Only one study compared the expression of TGF- $\beta$, BMPs and CTGF between different stages of human tendon disease in the RC. Seven studies compared the differences in the expression of at least one of the growth factors between tendinopathic and healthy tendon tissues in the patella, Achilles or RC (Table 1). However, the tissue was sampled from calcific tendinopathy patients in one study and another study compared the expression of the proteins after an intervention by exercise. Sixteen, seven and eight studies respectively reported the temporal expression of TGF- $\beta$, BMPs and CTGF in animal models of tendon injury or overuse (Table 2). The injury models varied by using the patella, Achilles, RC or flexor digitorum (FD) tendons in mice, rats, chickens, rabbits or horses, with injuries or defects created by transection, crush injury, use of collagenase or longitudinal division. Whether the transected tendons were repaired surgically or spontaneous healing was observed depended on the study. The development of tendinopathy was verified by histology in the overuse models, which used the RC or FD tendons in rats or rabbits. No study compared the differences in the cellular response to TGF- $\beta$, BMPs or CTGF in healthy and diseased cells from human tendons. One study used rat tendon cells from the patella of a collagenase-induced (CI) tendon injury model and another from a rat patella defect model, and treated the cells in vitro with BMP2 and TGF- $\beta$, respectively (Table 3 ). The cellular response to these growth factors was measured by the cell proliferation rate, expression of ECM-related genes and phosphorylation level of the Smad proteins, which are the key mediators of the TGF- $\beta$ and BMP cell-signaling pathway.

\section{Study methodology and assessing the risk of bias}

The quality of study methodology was assessed by referring to the modified scoring system by Dean et al. [21] in order to highlight the studies with a high risk of potential bias (Additional file 1). The mean (standard deviation) score was 7.73 (1.28) out of 10. All included studies had a control group, although in two studies the "control" samples were obtained from a macroscopically healthy area of the same tendon that may be at a risk of bias. Ten animal studies did not clarify the age or sex of the animals used. The methods of tissue and cell sampling and analysis were clearly described in all studies. Seven studies did not use quantitative measures or statistical analysis for comparison. The data were checked for normality in only four studies. All except 11 studies stated the set statistical significance. Two studies set $p<$ 0.01 with consideration for an increased type I error by performing multiple tests, but the remaining studies set $p<0.05$. The limitations of the study were not addressed 
Table 1 Main characteristics of studies and patients of the papers included for expression in the diseased human tendon tissues search

\begin{tabular}{|c|c|c|c|c|c|c|}
\hline Author & Year & Journal & Tendon & Healthy control? & $\begin{array}{l}\text { Quantitative/semiquantitative } \\
\text { analysis and statistical tests }\end{array}$ & Investigated genes and proteins \\
\hline \multicolumn{7}{|l|}{ TGF- $\beta$} \\
\hline Goodier et al. [22] & 2016 & Arthritis Res Ther & $\begin{array}{l}\text { Rotator } \\
\text { cuff }\end{array}$ & Yes & Yes & TGF $\beta 1$, TGF $\beta R 1$, TGF $\beta R 2$ \\
\hline Pingel et al. [25] & 2013 & Eur J Appl Physiol & Achilles & $Y_{e s}^{a}$ & Yes & TGFß1 \\
\hline Pingel et al. [27] & 2012 & $\begin{array}{l}\text { BMC Musculoskeletal } \\
\text { Disord }\end{array}$ & Achilles & $Y_{e s}^{a}$ & Yes & TGF $\beta 1$ \\
\hline de Mos et al. [28] & 2009 & Am J Sports Med & Achilles & Yes & Yes & TGF $\beta$ \\
\hline Fu et al. [24] & 2002 & Clin Orthop Relat Res & Patella & Yes & Yes & TGF $\beta 1$ \\
\hline Fenwick et al. [23] & 2001 & $J$ Anat & Achilles & $Y_{e s}^{b}$ & Yes & $\begin{array}{l}\text { TGF } \beta 1 \text {, TGF } \beta 2, \text { TGF } \beta 3, T G \beta R 1 \text {, } \\
\text { TG } 22\end{array}$ \\
\hline \multicolumn{7}{|l|}{ BMPs } \\
\hline Goodier et al. [22] & 2016 & Arthritis Res Ther & $\begin{array}{l}\text { Rotator } \\
\text { cuff }\end{array}$ & Yes & Yes & BMP2, BMP7 \\
\hline Rui et al. [26] & 2012 & $\begin{array}{l}\text { Knee Surg Sports Traumatol } \\
\text { Arthrosc }\end{array}$ & Patella & Yes & No & BMP2, BMP4, BMP7 \\
\hline Oliva et al. [29] & 2011 & Eur Cell Mater & $\begin{array}{l}\text { Rotator } \\
\text { cuff }\end{array}$ & $\mathrm{Yes}^{\mathrm{a}}$ & Yes & BMP2, BMP4, BMP6 \\
\hline \multicolumn{7}{|l|}{ CTGF } \\
\hline Goodier et al. [22] & 2016 & Arthritis Res Ther & $\begin{array}{l}\text { Rotator } \\
\text { cuff }\end{array}$ & Yes & Yes & CTGF \\
\hline Pingel et al. [27] & 2012 & $\begin{array}{l}\text { BMC Musculoskeletal } \\
\text { Disord }\end{array}$ & Achilles & $Y_{e s}^{a}$ & Yes & CTGF \\
\hline
\end{tabular}

${ }^{a}$ Studies that sampled control tissues from the macroscopically healthy region of the same tendon

${ }^{\text {b }}$ Studies that sampled control tissues from cadavers

$B M P$ bone morphogenic protein, CTGF connective tissue growth factor, TGF- $\beta$ transforming growth factor beta

in 13 studies. Meta-analysis was not performed due to the heterogeneity of the identified studies.

\section{Results}

\section{Expression of TGF- $\beta$, BMPs and CTGF in diseased human} tendon tissues

The expression of TGF- $\beta$, BMPs and CTGF was dysregulated at different stages of tendon disease (Table 4); the single study that compared the protein expression of these growth factors between torn, tendinopathic and healthy $\mathrm{RC}$ tissues reported a decreased expression of TGF- $\beta$ and its receptors in the diseased tendon tissues of both chronic tendinopathy and tear [22]. Gene and protein expression of TGF- $\beta$ and protein expression of BMP2, BMP4 and BMP7 were increased in the six studies that compared tendinopathy and healthy tendon tissues from the patella or the Achilles [23-28]. The gene expression of BMP4 and BMP6 was suppressed in the calcific area of calcific tendinopathy of the RC [29]. The diagnosis of chronic tendinopathy was made clinically in all seven studies of human disease, with auxiliary imaging methods such as MRI or US [22-28]. The duration of pain was defined as more than 3 and 6 months in one study [28] and in four studies [22, 25-27] respectively, but there was no clear explanation in the other two studies [23, 24]. The control tissues were obtained from the same anatomical location except in one study that investigated the gene expression in $\mathrm{RC}$ tear compared with the hamstring tendons in patients going under anterior cruciate ligament reconstruction surgery [22]. In the other studies that utilized the same anatomy, two studies obtained the control tissues from the unaffected area diagnosed by US in the same tendon [25, 27], and one study used cadaveric samples [23]. One study focused on a particular subtype of tendinopathy, calcific tendinopathy [29]. The two studies that investigated the gene expression of CTGF in RC tendon tear tissues did not show significant differences compared with the healthy tendon tissues [22, 27]. The studies investigating the effect of exercise in human tendons were excluded because the primary objective was to investigate the expression pattern across the spectrum of tendon disease and not to assess the impact of activity in tendons.

\section{Expression of TGF- $\beta$, BMPs and CTGF in animal models of tendon injury or overuse}

There was a wide variety of animal injury models, and the gene and protein expression of TGF- $\beta$ was predominantly increased in healing compared with healthy 
Table 2 Main characteristics of studies and animal models of the papers included for expression in the tendon injury or overuse model tissues search

\begin{tabular}{|c|c|c|c|c|c|c|c|}
\hline Author & Year & Journal & Tendon & Model & $\begin{array}{l}\text { Healthy } \\
\text { control? }\end{array}$ & $\begin{array}{l}\text { Quantitative/ } \\
\text { semiquantitative } \\
\text { analysis and } \\
\text { statistical tests }\end{array}$ & $\begin{array}{l}\text { Investigated genes } \\
\text { and proteins }\end{array}$ \\
\hline \multicolumn{8}{|l|}{ TGF- $\beta$} \\
\hline Zhang et al. [47] & 2016 & Matrix Biol & Achilles, mouse & Transection & Yes & Yes & $\begin{array}{l}\text { TGF } \beta 1 \text {, TGF } \beta 2, \text { TGF } \beta 3 \text {, } \\
\text { TGF } \beta R 1 \text {, TGF } \beta R 2\end{array}$ \\
\hline Gao et al. [30] & 2013 & Plos One & FD, rat & Overuse & Yes & Yes & TGF $\beta 1$ \\
\hline Heisterbach et al. [48] & 2012 & $\begin{array}{l}\text { Knee Surg Sports } \\
\text { Traumatol Arthrosc }\end{array}$ & Achilles, rat & Transection $\rightarrow$ repair & Yes & Yes & TGF $\beta 1$ \\
\hline Otoshi et al. [49] & 2011 & Arthroscopy & Achilles, rat & Removal & Yes & Yes & TGF $\beta 1$ \\
\hline Lin et al. [50] & 2010 & Bone & Achilles, rat & Transection & Yes & Yes & TGF $\beta 1$, TGF $\beta 2$, TGF $\beta 3$ \\
\hline Chen et al. [51] & 2008 & J Hand Surg Am & FDP, chicken & Transection $\rightarrow$ repair & Yes & Yes & TGF $\beta$ \\
\hline Chan et al. [52] & 2008 & Wound Repair Regen & Patella, rat & Defect & Yes & Yes & $\begin{array}{l}\text { TGF } \beta 1 \text {, TGF } \beta 2 \text {, TGF } \beta 3 \text {, } \\
\text { TGF } \beta R 1 \text {, TGF } \beta 22\end{array}$ \\
\hline Würgler-Hauri et al. [53] & 2007 & J Shoulder Elbow Surg & $\mathrm{RC}$, rat & Detach $\rightarrow$ repair & Yes & No & TGF $\beta 1$ \\
\hline Berglund et al. [54] & 2006 & J Hand Surg Am & FDP, rabbit & Division $\rightarrow$ repair & Yes & Yes & TGF $\beta 1$ \\
\hline Kobayashi et al. [55] & 2006 & J Shoulder Elbow Surg & $\mathrm{RC}$, rabbit & Defect & Yes & No & TGF $\beta$ \\
\hline Galatz et al. [56] & 2006 & J Orthop Res & $\mathrm{RC}$, rat & Transection $\rightarrow$ repair & Yes & Yes & TGF $\beta 1$, TGF $\beta 3$ \\
\hline Dahlgren et al. [57] & 2005 & J Orthop Res & FDS, horse & $\mathrm{Cl}$ & Yes & No & TGF $\beta 1$ \\
\hline Darmani et al. [58] & 2004 & Mediators Inflamm & FD, rat & Crush injury & Yes & No & TGF $\beta$ \\
\hline Ngo et al. [59] & 2001 & Plast Reconstr Surg & FDP, rabbit & Transection $\rightarrow$ repair & Yes & No & $\begin{array}{l}\text { TGF } \beta R 1, \text { TGF } \beta R 2, \\
\text { TGF } \beta R 3\end{array}$ \\
\hline Chang et al. [60] & 1997 & Plast Reconstr Surg & FDP, rabbit & Transection $\rightarrow$ repair & Yes & Yes & TGF $\beta 1$ \\
\hline Natsu-ume et al. [61] & 1997 & J Orthop Res & Patella, rat & Transection & Yes & Yes & TGF $\beta$ \\
\hline \multicolumn{8}{|l|}{ BMPs } \\
\hline Zhang et al. [47] & 2016 & Matrix Biol & Achilles, mouse & Transection & Yes & Yes & $\begin{array}{l}\text { BMP1- BMP7, BMP12- } \\
\text { BMP14, BMPR1, BMPR2 }\end{array}$ \\
\hline Heisterbach et al. [48] & 2012 & $\begin{array}{l}\text { Knee Surg Sports } \\
\text { Traumatol Arthrosc }\end{array}$ & Achilles, rat & Transection $\rightarrow$ repair & Yes & Yes & BMP12 \\
\hline Yee Lui et al. [62] & 2011 & J Orthop Res & Patella, rat & $\mathrm{Cl}$ & Yes & Yes & BMP2, BMP4, BMP7 \\
\hline Lin et al. [50] & 2010 & Bone & Achilles, rat & Transection & Yes & Yes & BMP2, BMP4, BMP7 \\
\hline Lui et al. [63] & 2009 & J Orthop Surg Res & Patella, rat & $\mathrm{Cl} /$ defect & Yes & Yes & BMP2 \\
\hline Eliasson et al. [64] & 2008 & Clin Orthop Relat Res & Achilles, rat & Transection & Yes & Yes & $\begin{array}{l}\text { BMP7, BMP12, BMP13, } \\
\text { BMP14, BMPR }\end{array}$ \\
\hline Würgler-Hauri et al. [53] & 2007 & J Shoulder Elbow Surg & $\mathrm{RC}$, rat & Detach $\rightarrow$ repair & Yes & No & BMP12, BMP13, BMP14 \\
\hline \multicolumn{8}{|l|}{ CTGF } \\
\hline Gao et al. [30] & 2013 & PLoS One & $\mathrm{FD}$, rat & Overuse & Yes & Yes & CTGF \\
\hline Kietrys et al. [31] & 2012 & PLoS One & FD, rat & Overuse & Yes & Yes & CTGF \\
\hline Fedorczyk et al. [32] & 2010 & J Orthop Res & FD, rat & Overuse & Yes & Yes & CTGF \\
\hline Chen et al. [51] & 2008 & $J$ Hand Surg Am & FDP, chicken & Transection & Yes & Yes & CTGF \\
\hline Asundi et al. [42] & 2008 & Eur J Appl Physiol & FDP, rabbit & Overuse & Yes & Yes & CTGF \\
\hline Würgler-Hauri et al. [53] & 2007 & J Shoulder Elbow Surg & $\mathrm{RC}$, rat & Detach $\rightarrow$ repair & Yes & No & CTGF \\
\hline Berglund et al. [54] & 2006 & J Hand Surg Am & FDP, rabbit & Division $\rightarrow$ repair & Yes & Yes & CTGF \\
\hline Nakama et al. [43] & 2006 & J Orthop Res & FDP, rabbit & Overuse & Yes & Yes & CTGF \\
\hline
\end{tabular}


Table 3 Main characteristics of studies and cells of the papers included for the cellular responses to treatment search

\begin{tabular}{llllllll}
\hline Author & Year & Journal & Tendon & Model & Healthy control? & $\begin{array}{l}\text { Quantitative/semiquantitative } \\
\text { analysis and statistical tests }\end{array}$ \\
\hline $\begin{array}{l}\text { TGF- } \beta \\
\text { Fu et al. [34] }\end{array}$ & 2008 & J Orthop Res & Patella, rat & Defect & Yes & Yes & TGF 31 \\
$\begin{array}{l}\text { BMPs } \\
\text { Lui and Wong [33] }\end{array}$ & 2013 & BMC Musculoskeletal Disord & Patella, rat & Cl & Yes & Yes & BMP2 \\
\hline
\end{tabular}

BMP bone morphogenic protein, $C l$ collagenase-induced, TGF- $\beta$ transforming growth factor beta

tendon tissues. However, the temporal pattern of the transition was inconsistent (Table 5). The expression of BMPs and CTGF was variable and could be increased, decreased or similar to that of the healthy tissues. In the overuse models, the expression of TGF- $\beta 1$ and CTGF proteins did not show changes in the early stages of intervention but increased after 3 months [30-32] (Table 5). No animal studies of tendon overuse focused on the expression of BMPs (Table 5).

\section{Response of tendon cells to treatment by TGF- $\beta$, BMPs or CTGF}

There were no studies that investigated the differences in the cellular response to treatment with TGF- $\beta$, BMPs

Table 4 Expression of TGF- $\beta$, BMPs and CTGF in diseased human tendon samples versus healthy control tendon

\begin{tabular}{|c|c|c|c|}
\hline & \multirow[t]{2}{*}{ Tendon } & \multicolumn{2}{|c|}{$\begin{array}{l}\text { Increased, unchanged, decreased in } \\
\text { diseased vs control }\end{array}$} \\
\hline & & Gene & Protein \\
\hline \multicolumn{4}{|c|}{ Tendinopathy } \\
\hline TGF $\beta$ & Achilles & $\uparrow[29]$ & \\
\hline TGF $\beta 1$ & RC, Achilles, patella & $\uparrow[25,27]$ & $\downarrow[22], \uparrow[24], \rightarrow[23]$ \\
\hline TGFß2 & Achilles & & $\uparrow[23]$ \\
\hline TGFß3 & Achilles & & $\rightarrow[23]$ \\
\hline TGFßR1 & RC, Achilles & & $\rightarrow[22,23]$ \\
\hline TGFßR2 & RC, Achilles & & $\downarrow[22,23]$ \\
\hline BMP2 & RC, patella & $\rightarrow[29]$ & $\uparrow[26]$ \\
\hline BMP4 & $\mathrm{RC}$, patella & $\downarrow[29]$ & $\uparrow[26]$ \\
\hline BMP6 & $\mathrm{RC}$ & $\downarrow[29]$ & \\
\hline BMP7 & Patella & & $\uparrow[26]$ \\
\hline CTGF & Achilles & $\rightarrow[27], \downarrow[25]$ & \\
\hline \multicolumn{4}{|l|}{ Tear } \\
\hline TGF $\beta 1$ & $\mathrm{RC}$ & $\rightarrow[22]$ & $\downarrow[22]$ \\
\hline TGF $\beta R 1$ & $\mathrm{RC}$ & $\downarrow[22]$ & $\downarrow[22]$ \\
\hline TGF $\beta R 2$ & $\mathrm{RC}$ & $\uparrow[22]$ & $\downarrow[22]$ \\
\hline BMP2 & $\mathrm{RC}$ & $\rightarrow[22]$ & \\
\hline BMP7 & $\mathrm{RC}$ & $\rightarrow[22]$ & \\
\hline CTGF & $\mathrm{RC}$ & $\rightarrow[22]$ & \\
\hline
\end{tabular}

$B M P$ bone morphogenic protein, CTGF connective tissue growth factor, $R C$ rotator cuff, TGF- $\beta$ transforming growth factor beta or CTGF by tendon cells from healthy and diseased human tendon tissues. Two studies used patella tendon derived cells from rat models of acute-stage tendon healing: one showed that diseased tendon cells from a CI tendon injury model had a higher cell signaling activity of the canonical Smad pathway in response to BMP stimulation compared with the healthy cells [33]; and the other reported that the expression of ECM genes such as collagens type I and III, decorin and biglycan to TGF- $\beta$ treatment goes through temporal changes during tendon healing in a defect model [34] (Table 6).

\section{Discussion}

This study provides evidence for the involvement of TGF- $\beta$, BMPs and CTGF in the pathogenesis and healing of tendon disease. Diseased tissues from tendinopathy and tendon tear patients showed an inconsistent expression of these fibrotic growth factors that could be increased, decreased or similar to that of the healthy tissues. We were not able to identify a consistent temporal pattern in their expression along the development of the disease. Differences in the cellular responses to TGF- $\beta$, BMPs and CTGF in diseased compared with healthy human tendon cells had not been considered. However, animal studies of tendon injury healing showed a variety of expression patterns of these growth factors over time, and that the cellular activities of these factors also differ according to the phase of the healing.

Because of the heterogeneity of the included studies, we were not able to determine a specific role of TGF- $\beta$, BMPs or CTGF in the development of tendon disease but only suggest their involvement in the pathogenesis of fibrotic repair. The general applicability of the results is limited. Clinical samples were harvested from tendinopathy patients in all of the human studies, but the diagnosis criteria were nonuniform and the anatomical location varied, which included the patella, Achilles and RC. Gene expression and stimulatory effects of the profibrotic growth factors on cells have been shown to differ by anatomical location in animal models [35, 36], and this is likely also the case for humans although we did not identify any studies assessing anatomical location in humans. The selection of matched control tissues with regards to clinical and ethical feasibility is another 
Table 5 Expression of TGF- $\beta$, BMPs and CTGF in animal models of tendon injury or overuse versus healthy control tendon

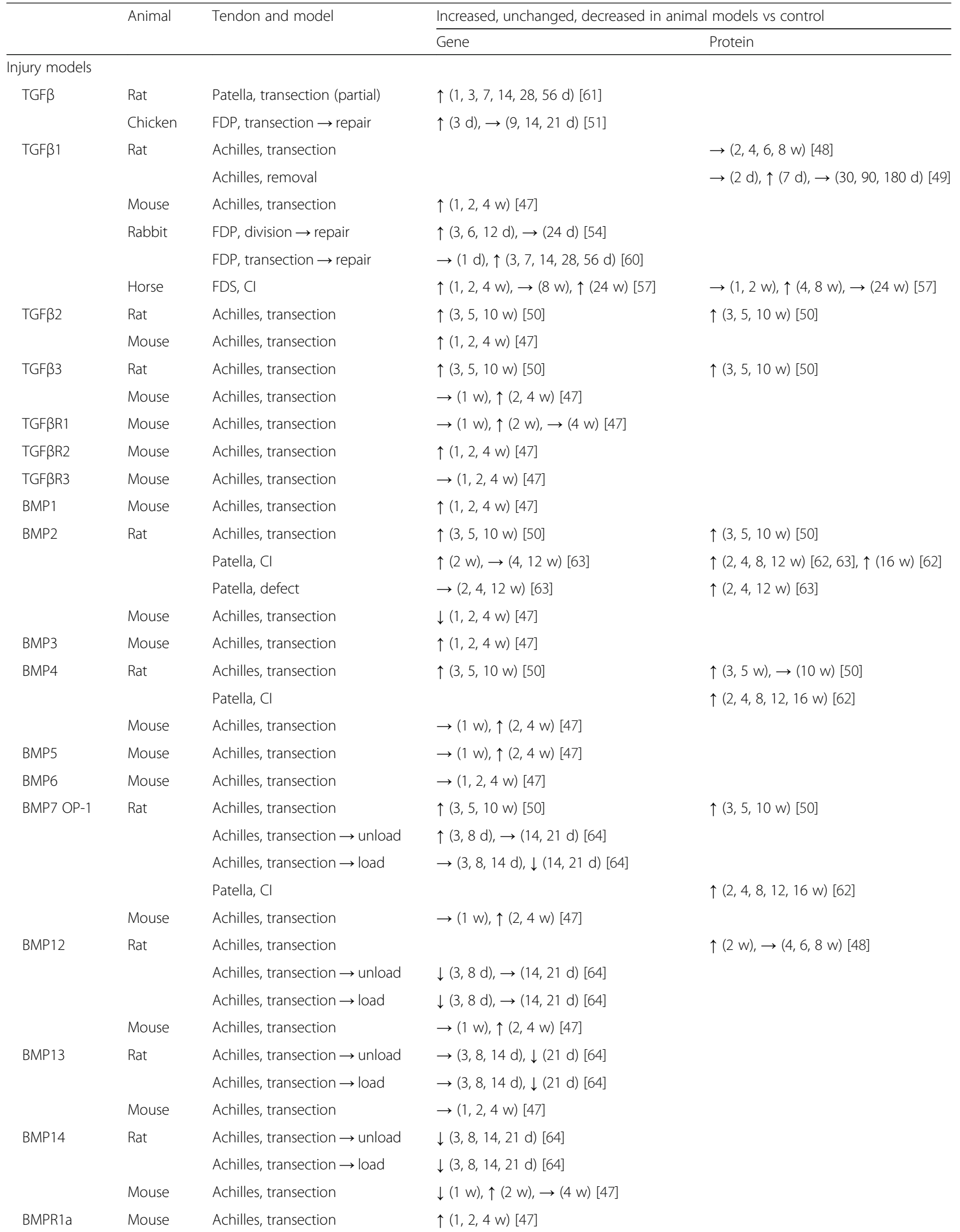


Table 5 Expression of TGF- $\beta$, BMPs and CTGF in animal models of tendon injury or overuse versus healthy control tendon (Continued)

\begin{tabular}{|c|c|c|c|c|}
\hline \multirow[t]{3}{*}{ BMPR1b } & \multirow[t]{2}{*}{ Rat } & Achilles, transection $\rightarrow$ unload & \multicolumn{2}{|l|}{$\downarrow(3 \mathrm{~d}), \rightarrow(8 \mathrm{~d}), \uparrow(14 \mathrm{~d}), \downarrow(21 \mathrm{~d})[64]$} \\
\hline & & Achilles, transection $\rightarrow$ load & \multicolumn{2}{|l|}{$\rightarrow(3,8,14 \mathrm{~d}), \downarrow(21 \mathrm{~d})[64]$} \\
\hline & Mouse & Achilles, transection & \multicolumn{2}{|l|}{$\rightarrow(1 \mathrm{w}), \uparrow(2,4 \mathrm{w})[47]$} \\
\hline \multirow[t]{3}{*}{ BMPR2 } & \multirow[t]{2}{*}{ Rat } & Achilles, transection $\rightarrow$ unload & \multicolumn{2}{|l|}{$\rightarrow(3 \mathrm{~d}), \uparrow(8,14 \mathrm{~d}), \downarrow(21 \mathrm{~d})[64]$} \\
\hline & & Achilles, transection $\rightarrow$ load & \multicolumn{2}{|l|}{$\rightarrow(3 \mathrm{~d}), \uparrow(8,14 \mathrm{~d}), \downarrow(21 \mathrm{~d})[64]$} \\
\hline & Mouse & Achilles, transection & \multicolumn{2}{|l|}{$\uparrow(1,2,4 w)[47]$} \\
\hline \multirow[t]{2}{*}{ CTGF } & Rabbit & FDP, division $\rightarrow$ repair & \multicolumn{2}{|l|}{$\rightarrow(3,6,12,24$ d) $[54]$} \\
\hline & Chicken & FDP, transection $\rightarrow$ repair & \multicolumn{2}{|l|}{$\uparrow(3 \mathrm{~d}), \rightarrow(9 \mathrm{~d}), \downarrow(14,21 \mathrm{~d})[51]$} \\
\hline \multicolumn{5}{|c|}{ Overuse models } \\
\hline TGF $\beta 1$ & Rat & FD, hand-pulling task & & $\rightarrow(18 w), \uparrow(24 w)[30]$ \\
\hline \multirow[t]{4}{*}{ CTGF } & \multirow[t]{3}{*}{ Rat } & RC, hand-pulling task & & $\uparrow(12 w)[31]$ \\
\hline & & FD, hand-pulling task & & $\uparrow(18,24 w)[30]$ \\
\hline & & & & $\rightarrow(3,6 w), \uparrow(12 w)[32]$ \\
\hline & Rabbit & FDP, electrical stimulation & $\rightarrow[42]$ & $\uparrow[43]$ \\
\hline
\end{tabular}

BMP bone morphogenic protein, $C l$ collagenase-induced, CTGF connective tissue growth factor, $d$ day(s), FD flexor digitorum, FDP flexor digitorum profundus, FDS flexor digitorum superficialis, $R C$ rotator cuff, TGF- $\beta$ transforming growth factor beta, $w$ week(s)

concern. In one study the control tissues were obtained from the hamstring tendons in patients going under anterior cruciate ligament reconstruction surgery in comparison with RC tear tendons [22], with an age difference between the two cohorts that could be a potential confounder in humans [37-39], unlike animals [40]. Whether an ultrasonographically intact region of a diseased tendon represents a healthy tissue remains controversial, and cadaveric tissue samples have their limitations in the traceability of tendon disease history and the effects of postmortem change [22].

For the studies of animal tendon injury models, only the studies that measured the temporal changes were included so that the results came in line with the primary objective of assessing differences between the stages of a tendon disease. Only the studies that used quantitative measures and statistical methods for comparison for their results were included (Table 5), but there was also a variation in the methods of analysis. Various animal models of tendinopathy have been proposed, but

Table 6 Cellular responses to treatment by TGF- $\beta$ and BMPs in injured versus healthy tendon cells

\begin{tabular}{|c|c|c|c|}
\hline & & $\begin{array}{l}\text { Increased, unchanged, decre } \\
\text { vs control }\end{array}$ & sed in diseased \\
\hline Treatment & Cells & Gene & Protein \\
\hline TGF $\beta 1$ & $\begin{array}{l}\text { Patella, } \\
\text { rat, defect }\end{array}$ & $\begin{array}{l}\text { Col1a1 } \rightarrow \text {, Col3a1 } \uparrow, \text { Den } \uparrow, \\
\text { Bgn } \rightarrow \text { (day } 7 \text { healing) [34] } \\
\text { Col1a1 } \rightarrow \text {, Col3a1 } \rightarrow \text {, Dcn } \uparrow, \\
\text { Bgn } \downarrow \text { (day } 14 \text { healing) }[34]\end{array}$ & \\
\hline BMP2 & Patella, rat, Cl & & $\begin{array}{l}\text { p-Smad1/5/ } \\
8 \uparrow[33]\end{array}$ \\
\hline
\end{tabular}

BMP bone morphogenic protein, $\mathrm{Cl}$ collagenase-induced, TGF- $\beta$ transforming growth factor beta because they do not always account for the effects of aging and development of fibrosis, whether they accurately recapitulate human disease is open to debate [41]. We included the studies of overuse models that confirmed the development of tendinopathy after the intervention with (semi)quantitative methods such as changes in cellularity [30,31], infiltration of inflammatory cells [32] and disorganized collagen fibers by histology $[42,43]$. The expression of TGF- $\beta 1$ and CTGF proteins increased after 3 months of overloading tasks corresponding to tendinopathy development, but not in the early stages of intervention [30-32].

We have indicated that the gene and protein expression of TGF- $\beta$ and BMPs varies across the stage of tendon disease, and that cellular activities go through changes accordingly. This is in line with a previous study reporting the differences in the cellular response to TGF- $\beta$ in human fibroblasts derived from normal skin and the skin of a hypertrophic scar [44]. Involvement of CTGF could not be established in human disease because only two studies looked at this growth factor [22, 25], and no difference in gene expression between healthy and diseased tendon was detected. There were also no studies that investigated differences in cellular activities in response to CTGF between cells from different stages of a tendon disease or injury healing. Further investigation is necessary to enhance our understanding of the role of TGF- $\beta$, BMPs and CTGF in tendon disease.

This review also highlights the paucity of analyses of human-derived tendon tissue and cells. The majority of studies to date have attempted to modify disease progression or improve healing by adjusting the expression of the fibrotic mediators that was found to be 
remarkable in diseased tendons, without a comprehensive understanding of their role and mechanisms in the development of the disease. Cells from clinical samples of tendinopathy show an altered phenotype [45] and the cellular activities of $\mathrm{RC}$ tear tendon cells may likewise differ according to the severity of the disease [46]. Despite these differential cellular responses, the majority of in vitro tendinopathy studies have not taken this into account. It is imperative to recognize that cultured tendon cells from intact as opposed to diseased tendons may not recapitulate the actual healing or disease development process with regards to cell proliferation and synthesis of ECM proteins [45]. Animal models have been beneficial in increasing the understanding of tendon disease progression and healing, but do not replicate the continuum of tendon disease [22]. It should be noted that cautious interpretation of animal studies is necessary. The most effective method to investigate the mechanism of human tendon pathophysiology is to use fresh well-phenotyped tissue from human patients with acceptable control samples. Understanding the interaction of cells and fibrotic mediators that drive fibrosis in the pathophysiology of tendon disease would be essential in order to identify the fundamental interventions, and therefore it is critical to appropriately define the details of the specimen such as origin of the tissues or cell, phase of the disease, criteria and method of diagnosis. In tendon disease, the importance of considering the appropriate disease phase and the corresponding intervention has been recognized [19]; however, the sequential regulation and interaction of the TGF- $\beta$, BMPs and CTGF with tendon cells is not yet well understood. Future work should investigate the temporal expression of these fibrotic growth factors and their interaction with tendon cells using well-phenotyped patient samples at different stages of tendon disease. This research will advance our knowledge of the pathophysiology of tendon disease, and will facilitate identification of potential therapeutic targets to enhance the quality of tissue repair or influence disease progression.

\section{Conclusions}

The expression of the TGF- $\beta$, BMPs and CTGF is dysregulated in diseased human tendon tissues, but the transition during the development of the disease is yet to be defined. Cell behavior in response to these growth factors in human tendon cells along the course of pathology has not been explored. Importantly this review highlights the paucity of analyses of human-derived tendon tissues and cells. Further research using wellphenotyped patient samples at different stages of tendon disease is warranted to improve the understanding of disease pathogenesis.

\section{Additional file}

Additional file 1: Presenting assessment of study methodology quality. The quality of methodology was assessed in the included 33 studies in order to highlight the reports with a high risk of potential bias. (XLS 41 kb)

\section{Abbreviations}

BMP: Bone morphogenic protein; Cl: Collagenase-induced; CTGF: Connective tissue growth factor; ECM: Extracellular matrix; FD: Flexor digitorum;

PRISMA: Preferred Reporting Items for Systematic Reviews and Meta-analyses; RC: Rotator cuff; TGF- $\beta$ : Transforming growth factor beta

\section{Acknowledgements}

Not applicable.

\section{Funding}

This work was funded by the National Institute for Health Research (NIHR) through the Oxford Musculoskeletal Biomedical Research Unit. Dr Morita, Dr Snelling and Dr Dakin are funded by 28th Term Scholarship No. 274 of the INOAC International Education and Scholarship Foundation, Arthritis

Research UK (grants 20087 and 20506), respectively.

\section{Availability of data and materials}

The data supporting the conclusions of this article are included within the article and its additional files.

\section{Authors' contributions}

WM participated in the design of the study, carried out the data collection and analysis, and drafted the manuscript. SJBS participated in the design of the study, interpretation of the data and critical revision of the manuscript. SGD participated in the design of the study, interpretation of the data and critical revision of the manuscript. AJC participated in the design of the

study and critical revision of the manuscript. All authors read and approved the final manuscript.

\section{Authors' information}

Not applicable.

\section{Competing interests}

The authors declare that they have no competing interests.

\section{Consent for publication}

Not applicable.

Ethical approval and consent to participate Not applicable.

\section{Submission declaration}

This work has not been published nor under consideration for publication elsewhere.

Received: 25 July 2016 Accepted: 25 October 2016

Published online: 18 November 2016

\section{References}

1. Rees JD, Stride M, Scott A. Tendons - time to revisit inflammation. Br J Sports Med. 2014:48(21):1553-7.

2. Riley $\mathrm{G}$. The pathogenesis of tendinopathy. A molecular perspective. Rheumatology. 2004;43(2):131-42.

3. Forde MS, Punnett $L$, Wegman DH. Prevalence of musculoskeletal disorders in union ironworkers. J Occup Environ Hyg. 2005;2(4):203-12.

4. Riley G. Tendinopathy-from basic science to treatment. Nat Clin Pract Rheumatol. 2008;4(2):82-89.

5. Wang JH, losifidis Ml, Fu FH. Biomechanical basis for tendinopathy. Clin Orthop Relat Res. 2006;443:320-32.

6. Neer CS, Welsh RP. Shoulder in Sports. Orthop Clin N Am. 1977;8(3):583-91.

7. Cook JL, Purdam CR. Is tendon pathology a continuum? A pathology model to explain the clinical presentation of load-induced tendinopathy. $\mathrm{Br}$ J Sports Med. 2009;43(6):409-16. 
8. van der Windt DA, Koes BW, de Jong BA, Bouter LM. Shoulder disorders in general practice: incidence, patient characteristics, and management. Ann Rheum Dis. 1995;54(12):959-64.

9. Yamaguchi K, Ditsios K, Middleton WD, Hildebolt CF, Galatz LM, Teefey SA The demographic and morphological features of rotator cuff disease. A comparison of asymptomatic and symptomatic shoulders. J Bone Jt Surg Am Vol. 2006;88(8):1699-704

10. Dakin SG, Martinez FO, Yapp C, Wells G, Oppermann U, Dean BJ, Smith RD, Wheway $K$, Watkins $B$, Roche $L$, et al. Inflammation activation and resolution in human tendon disease. Sci Transl Med. 2015;7(311):311ra173.

11. Sharma P, Maffulli N. Biology of tendon injury: healing, modeling and remodeling. J Musculoskelet Neuronal Interactions. 2006;6(2):181-90.

12. Schulze-Tanzil G, Al-Sadi O, Wiegand E, Ertel W, Busch C, Kohl B, Pufe T. The role of pro-inflammatory and immunoregulatory cytokines in tendon healing and rupture: new insights. Scand J Med Sci Sports. 2011;21(3):337-51.

13. Carr AJ, Rees JL, Ramsay CR, Fitzpatrick R, Gray A, Moser J, Dawson J, Bruhn H, Cooper CD, Beard DJ, et al. Protocol for the United Kingdom Rotator Cuff Study (UKUFF): a randomised controlled trial of open and arthroscopic rotator cuff repair. Bone Jt Res. 2014;3(5):155-60.

14. Biernacka A, Dobaczewski M, Frangogiannis NG. TGF-beta signaling in fibrosis. Growth Factors. 2011:29(5):196-202.

15. Neuman MG, Schmilovitz-Weiss H, Hilzenrat N, Bourliere M, Marcellin P, Trepo C, Mazulli T, Moussa G, Patel A, Baig AA, et al. Markers of inflammation and fibrosis in alcoholic hepatitis and viral hepatitis C. Int J Hepatol. 2012;2012:231210

16. Wang S, Hirschberg R. Bone morphogenetic protein-7 signals opposing transforming growth factor beta in mesangial cells. J Biol Chem. 2004;279(22):23200-6.

17. Bedossa P, Peltier E, Terris B, Franco D, Poynard T. Transforming growth factor-beta 1 (TGF-beta 1) and TGF-beta 1 receptors in normal, cirrhotic, and neoplastic human livers. Hepatology. 1995;21(3):760-6.

18. El-Bassiouny AE, Zoheiry MM, Nosseir MM, El-Ahwany EG, Ibrahim RA, ElBassiouni NE. Expression of cyclooxygenase-2 and transforming growth factor-beta1 in HCV-induced chronic liver disease and hepatocellular carcinoma. MedGenMed. 2007;9(3):45.

19. Dooley S, ten Dijke P. TGF-beta in progression of liver disease. Cell Tissue Res. 2012;347(1):245-56.

20. Hast MW, Zuskov A, Soslowsky $\sqcup$ J. The role of animal models in tendon research. Bone Jt Res. 2014;3(6):193-202.

21. Dean BJ, Gettings P, Dakin SG, Carr AJ. Are inflammatory cells increased in painful human tendinopathy? A systematic review. Br J Sports Med. 2016;50(4):216-20.

22. Goodier HC, Carr AJ, Snelling SJ, Roche L, Wheway K, Watkins B, Dakin SG. Comparison of transforming growth factor beta expression in healthy and diseased human tendon. Arthritis Res Ther. 2016;18:48.

23. Fenwick SA, Curry V, Harrall RL, Hazleman BL, Hackney R, Riley GP. Expression of transforming growth factor-beta isoforms and their receptors in chronic tendinosis. J Anat. 2001;199(Pt 3):231-40.

24. Fu SC, Wang W, Pau HM, Wong YP, Chan KM, Rolf CG. Increased expression of transforming growth factor-beta1 in patellar tendinosis. Clin Orthop Relat Res. 2002:400:174-83.

25. Pingel J, Fredberg U, Mikkelsen LR, Schjerling $P$, Heinemeier KM, Kjaer $M$, Harisson $\mathrm{A}$, Langberg $\mathrm{H}$. No inflammatory gene-expression response to acute exercise in human Achilles tendinopathy. Eur J Appl Physiol. 2013:113(8):2101-9.

26. Rui YF, Lui PP, Rolf CG, Wong YM, Lee YW, Chan KM. Expression of chondroosteogenic BMPs in clinical samples of patellar tendinopathy. Knee Surg Sports Traumatol Arthrosc. 2012;20(7):1409-17.

27. Pingel J, Fredberg U, Qvortrup K, Larsen JO, Schjerling P, Heinemeier KM, Kjaer M, Langberg H. Local biochemical and morphological differences in human Achilles tendinopathy: a case control study. BMC Musculoskelet Disord. 2012;13:53.

28. de Mos M, Koevoet W, van Schie HT, Kops N, Jahr H, Verhaar JA, van Osch GJ. In vitro model to study chondrogenic differentiation in tendinopathy. Am J Sports Med. 2009;37(6):1214-22.

29. Oliva F, Barisani D, Grasso A, Maffulli N. Gene expression analysis in calcific tendinopathy of the rotator cuff. Eur Cells Mater. 2011;21:548-57.

30. Gao HG, Fisher PW, Lambi AG, Wade CK, Barr-Gillespie AE, Popoff SN, Barbe MF. Increased serum and musculotendinous fibrogenic proteins following persistent low-grade inflammation in a rat model of long-term upper extremity overuse. PLoS One. 2013;8(8):e71875.
31. Kietrys DM, Barr-Gillespie AE, Amin M, Wade CK, Popoff SN, Barbe MF. Aging contributes to inflammation in upper extremity tendons and declines in forelimb agility in a rat model of upper extremity overuse. PLoS One. 2012:7(10):e46954.

32. Fedorczyk JM, Barr AE, Rani S, Gao HG, Amin M, Amin S, Litvin J, Barbe MF. Exposure-dependent increases in IL-1beta, substance P, CTGF, and tendinosis in flexor digitorum tendons with upper extremity repetitive strain injury. J Orthop Res. 2010;28(3):298-307.

33. Lui PP, Wong Y. Higher BMP/Smad sensitivity of tendon-derived stem cells (TDSCS) isolated from the collagenase-induced tendon injury model: possible mechanism for their altered fate in vitro. BMC Musculoskelet Disord. 2013;14:248.

34. Fu SC, Cheuk YC, Chan KM, Hung LK, Wong MW. Is cultured tendon fibroblast a good model to study tendon healing? J Orthop Res. 2008:26(3):374-83.

35. Yeh LC, Tsai AD, Lee JC. Bone morphogenetic protein-7 regulates differentially the mRNA expression of bone morphogenetic proteins and their receptors in rat achilles and patellar tendon cell cultures. J Cell Biochem. 2008;104(6):2107-22.

36. Spindler KP, Imro AK, Mayes CE, Davidson JM. Patellar tendon and anterior cruciate ligament have different mitogenic responses to platelet-derived growth factor and transforming growth factor beta. J Orthop Res. 1996;14(4):542-6.

37. Klatte-Schulz F, Pauly S, Scheibel M, Greiner S, Gerhardt C, Hartwig J, Schmidmaier G, Wildemann B. Characteristics and stimulation potential with BMP-2 and BMP-7 of tenocyte-like cells isolated from the rotator cuff of female donors. PLoS One. 2013;8(6):e67209.

38. Klatte-Schulz F, Pauly S, Scheibel M, Greiner S, Gerhardt C, Schmidmaier G Wildemann B. Influence of age on the cell biological characteristics and the stimulation potential of male human tenocyte-like cells. Eur Cells Mater. 2012;24:74-89.

39. Goodman SA, May SA, Heinegard D, Smith RK. Tenocyte response to cyclical strain and transforming growth factor beta is dependent upon age and site of origin. Biorheology. 2004;41(5):613-28.

40. Kostrominova TY, Brooks SV. Age-related changes in structure and extracellular matrix protein expression levels in rat tendons. Age (Dordr). 2013;35(6):2203-14.

41. Lui PP, Maffulli N, Rolf C, Smith RK. What are the validated animal models for tendinopathy? Scand J Med Sci Sports. 2011;21(1):3-17.

42. Asundi KR, King KB, Rempel DM. Evaluation of gene expression through qRT-PCR in cyclically loaded tendons: an in vivo model. Eur J Appl Physiol. 2008;102(3):265-70.

43. Nakama LH, King KB, Abrahamsson S, Rempel DM. VEGF, VEGFR-1, and CTGF cell densities in tendon are increased with cyclical loading: An in vivo tendinopathy model. J Orthop Res. 2006;24(3):393-400.

44. Garner WL, Rittenberg T, Ehrlich HP, Karmiol S, Rodriguez JL, Smith DJ, Phan $\mathrm{SH}$. Hypertrophic scar fibroblasts accelerate collagen gel contraction. Wound Repair Regen. 1995;3(2):185-91.

45. Rolf CG, Fu BS, Pau A, Wang W, Chan B. Increased cell proliferation and associated expression of PDGFRbeta causing hypercellularity in patellar tendinosis. Rheumatology. 2001;40(3):256-61.

46. Klatte-Schulz F, Gerhardt C, Scheibel M, Wildemann B, Pauly S. Relationship between muscle fatty infiltration and the biological characteristics and stimulation potential of tenocytes from rotator cuff tears. J Orthop Res. 2014:32(1):129-37.

47. Zhang K, Asai S, Hast MW, Liu M, Usami Y, Iwamoto M, Soslowsky LJ, Enomoto-Iwamoto M. Tendon mineralization is progressive and associated with deterioration of tendon biomechanical properties, and requires BMPSmad signaling in the mouse Achilles tendon injury model. Matrix Biol. 2016:52-54:315-24.

48. Heisterbach PE, Todorov A, Fluckiger R, Evans CH, Majewski M. Effect of BMP-12, TGF-beta1 and autologous conditioned serum on growth factor expression in Achilles tendon healing. Knee Surg Sports Traumatol Arthrosc. 2012;20(10):1907-14.

49. Otoshi K, Kikuchi S, Ohi G, Numazaki H, Sekiguchi M, Konno S. The process of tendon regeneration in an achilles tendon resection rat model as a model for hamstring regeneration after harvesting for anterior cruciate ligament reconstruction. Arthroscopy. 2011;27(2):218-27.

50. Lin L, Shen Q, Xue T, Yu C. Heterotopic ossification induced by Achilles tenotomy via endochondral bone formation: expression of bone and cartilage related genes. Bone. 2010;46(2):425-31. 
51. Chen CH, Cao Y, Wu YF, Bais AJ, Gao JS, Tang JB. Tendon healing in vivo: gene expression and production of multiple growth factors in early tendon healing period. J Hand Surg. 2008;33(10):1834-42.

52. Chan KM, Fu SC, Wong YP, Hui WC, Cheuk YC, Wong MW. Expression of transforming growth factor beta isoforms and their roles in tendon healing. Wound Repair Regen. 2008;16(3):399-407.

53. Würgler-Hauri CC, Dourte LM, Baradet TC, Williams GR, Soslowsky LJ. Temporal expression of 8 growth factors in tendon-to-bone healing in a rat supraspinatus model. J Shoulder Elbow Surg. 2007;16(5 Suppl):S198-203.

54. Berglund M, Reno C, Hart DA, Wiig M. Patterns of mRNA expression for matrix molecules and growth factors in flexor tendon injury: differences in the regulation between tendon and tendon sheath. J Hand Surg. 2006:31(8):1279-87.

55. Kobayashi M, Itoi E, Minagawa H, Miyakoshi N, Takahashi S, Tuoheti Y, Okada K, Shimada Y. Expression of growth factors in the early phase of supraspinatus tendon healing in rabbits. J Should Elb Surg. 2006;15(3):371-7.

56. Galatz LM, Sandell LJ, Rothermich SY, Das R, Mastny A, Havlioglu N, Silva MJ, Thomopoulos S. Characteristics of the rat supraspinatus tendon during tendon-to-bone healing after acute injury. J Orthop Res. 2006;24(3):541-50.

57. Dahlgren LA, Mohammed HO, Nixon AJ. Temporal expression of growth factors and matrix molecules in healing tendon lesions. J Orthop Res. 2005:23(1):84-92.

58. Darmani H, Crossan J, McLellan SD, Meek D, Adam C. Expression of nitric oxide synthase and transforming growth factor-beta in crush-injured tendon and synovium. Mediators Inflamm. 2004;13(5-6):299-305.

59. Ngo M, Pham H, Longaker MT, Chang J. Differential expression of transforming growth factor-beta receptors in a rabbit zone $\|$ flexor tendon wound healing model. Plast Reconstr Surg. 2001;108(5):1260-7.

60. Chang J, Most D, Stelnicki E, Siebert JW, Longaker MT, Hui K, Lineaweaver WC. Gene expression of transforming growth factor beta-1 in rabbit zone II flexor tendon wound healing: evidence for dual mechanisms of repair. Plast Reconstr Surg. 1997;100(4):937-44.

61. Natsu-ume T, Nakamura N, Shino K, Toritsuka Y, Horibe S, Ochi T. Temporal and spatial expression of transforming growth factor-beta in the healing patellar ligament of the rat. J Orthop Res. 1997;15(6):837-43.

62. Yee Lui PP, Wong YM, Rui YF, Lee YW, Chan LS, Chan KM. Expression of chondro-osteogenic BMPs in ossified failed tendon healing model of tendinopathy. J Orthop Res. 2011;29(6):816-21.

63. Lui PP, Chan LS, Cheuk YC, Lee YW, Chan KM. Expression of bone morphogenetic protein-2 in the chondrogenic and ossifying sites of calcific tendinopathy and traumatic tendon injury rat models. J Orthop Surg Res. 2009;4:27.

64. Eliasson P, Fahlgren A, Aspenberg P. Mechanical load and BMP signaling during tendon repair: a role for follistatin? Clin Orthop Relat Res. 2008;466(7):1592-7.

\section{Submit your next manuscript to BioMed Central and we will help you at every step:}

- We accept pre-submission inquiries

- Our selector tool helps you to find the most relevant journal

- We provide round the clock customer support

- Convenient online submission

- Thorough peer review

- Inclusion in PubMed and all major indexing services

- Maximum visibility for your research

Submit your manuscript at www.biomedcentral.com/submit 